\title{
The Role of Female Characters in the Narrator's Quest for Identity in John Banville's Eclipse
}

\author{
Mar Asensio Aróstegui \\ University of La Rioja, Spain
}

Copyright (c) 2018 by Mar Asensio Aróstegui. This text may be archived and redistributed both in electronic form and in hard copy, provided that the author and journal are properly cited and no fee is charged for access.

\begin{abstract}
Eclipse is a novel that contributes to John Banville's idiosyncratic worlds of fiction in presenting the reader with a male narrator who engages in the telling of a journey back to the spatial context of his childhood in an attempt to retrieve what he deems to have lost, his true self. Criticism on the novel has dealt with the narrator's narcissism, the novel's narrative style and technique, its modernist/postmodernist allegiance, its intertextual and intermedial nature and its status as trauma narrative. A few attempts have also been made at revisiting the novel from the standpoint of gender, although women have been invariably read as subject to the male gaze, whether as mundane objects of desire or idealized objets d'art. This article aims at showing that women in Eclipse refuse to be mere erotic or artistic objects in a male story. In my view, the narrative centrality of the male figure is progressively challenged by the female characters, both puzzling and fascinating, who stubbornly keep on intruding into the narrator's solipsistic activities, eventually break free from their usual position as objects of the male gaze and redirect the narrator's quest and his narrative into an unexpected, moving finale.
\end{abstract}

Key Words. Gender, Identity, Ghost, Eclipse, John Banville.

Resumen. Eclipse es una novela que contribuye a la idiosincrasia de los mundos ficticios de John Banville presentando al lector un narrador masculino que se embarcará en el relato de un viaje al contexto espacial de su infancia, en un intento de recuperar lo que considera haber perdido, su verdadero yo. La crítica ha girado en torno al narcisismo del narrador, al estilo narrativo y la técnica de la novela, su fidelidad a los parámetros modernistas/postmodernistas, su naturaleza intertextual e intermedia y su condición de narrativa sobre trauma. Asimismo, se han hecho diversas aproximaciones al estudio de la novela desde una perspectiva de género, aunque las mujeres han sido invariablemente consideradas como objetivo de la mirada masculina, tanto como objetos mundanos de deseo o como idealizados objetos de arte. Este artículo pretende demostrar que las mujeres en Eclipse se niegan a ser meros objetos eróticos o artísticos en una historia de hombres. Desde mi punto de vista, la centralidad narrativa de la figura masculina se ve progresivamente amenazada por los personajes femeninos, tan desconcertantes como fascinantes, quienes inmiscuyéndose obstinadamente en las actividades 
solipsistas del narrador, finalmente consiguen liberarse de su posición habitual de objetos de la mirada masculina, redirigiendo la misión y la narrativa del narrador hacia un final inesperado y conmovedor.

Palabras clave. Género, identidad, fantasma, Eclipse, John Banville.

\section{Introduction}

The Irish writer John Banville has been producing works of fiction at the average rate of roughly a novel every three years for over three decades. ${ }^{1}$ This regularity finds a reflection in his allegiance to a set of themes, motifs, and techniques which keep on recurring in his novels from the very beginning of his writing career. According to Derek Hand, "Banville has created a world, or rather worlds, of fiction without parallel in Irish writing" ("Quixotic" viii). These worlds of fiction systematically explore and develop the author's personal concerns and narrative preoccupations.

In my view, it is the voice of the narrator as central figure in Banville's novels that brings together the author's personal concerns and narrative preoccupations. ${ }^{2}$ Banville's narrators are characteristically white, upper-middle-class, self-centered males, who speak in the first person - mostly about themselves ${ }^{3}$ - are aware of the unreliability of both their immediate perceptions and their past memories and present themselves to the reader as conscious or unconscious deceivers who, paradoxically enough, yearn for objective knowledge and, consequently, strive hard to unveil their authentic selves. ${ }^{4}$

Banville's narrators echo one another to explore the same themes once and again. In the words of the Irish critic Eoghan Smith, those themes are "the life of the imagination, the search for authenticity with all its attendant psychological and philosophical difficulties, the unavoidable invention of multiple selves, the problem of subjectivity, and the nature and purpose of art" (n.p.). Consciously aware of the constructed nature of their narratives and of the impossibility of apprehending reality, Banville's narrators resort to the profuse use of metafictional digressions, whose lavishness at times threatens the continuity of plots, and of literary and artistic allusions, which endow their narratives with a multiplicity of layers of meaning. ${ }^{5}$

Banville's worlds of fiction have traditionally been read as masculine by the Academy. According to Carol Dell'Amico, the first critic to initiate "the discussion about gender in Banville" was Joseph McMinn. In John Banville: A Critical Study (1991), McMinn "conveyed ... the approach to Banville as a fundamentally masculine author that he would reiterate in his second study [The Supreme Fictions of John Banville (1999)]" (109). Dell'Amico points out that this approach has been followed by some of the writer's most authoritative critics: "Derek Hand, Ruth Frehner, and Patricia Coughlan have built on McMinn's ideas" (111). Dell'Amico also regrets that "[a]ssembling a selection of gendered elements as reflections on Banville's corresponding gender and sexual imaginary [sic], the critics continue to pass over contradictory elements and suggest that a masculinist aesthetic shapes the writing" (111). In his study on subjectivity in Banville's works, Mehdi Ghassemi similarly argues that 'the narrators 'use' the figure of 'the woman' to heal the rift between them and the natural world and to reconstitute their precarious sense of self ... This leads the female characters to be subjected to the narrator's phallic vision" (204). As a result, female characters in Banville's works seem mostly to spring from the narrators' minds as both objects of desire and objects of their epistemological quest. They appear as blurred, shadowy or insubstantial figures and, when they are endowed with corporeality, it is not as full human beings but rather as artistic products born from the hand or the pen of the narrator. 
Eclipse (2000) is, in many respects, a representative example of Banville's worlds of fiction. Apart from the fact that it is ripe with the customary dose of narrative selfconsciousness and intertextuality, ${ }^{6}$ the novel presents the reader with a conspicuously narcissistic male narrator who, at a moment of personal and professional crisis, engages in the telling of an actual journey back to the spatial context of his childhood in an attempt to be on his own and to retrieve his long lost true self. His epistemological and ontological concerns become the key substance of his story. However, what makes of Eclipse an especially interesting case study from the point of view of gender is that the centrality of the male figure is progressively decentred by the agency of a feminine other, both puzzling and fascinating, who stubbornly keeps on intruding on the narrator's solipsistic activities. ${ }^{7}$ In Eclipse, the narrator himself and the space in which he takes refuge, the family house and its surroundings, are inhabited by female presences who, although in not so grand or noisy a manner as the narrator's, eventually break free from their usual position as objects of the male gaze and redirect the narrator's quest and his narrative into an unexpected, moving finale. What is more, those female presences are both flesh and blood women sharing the same physical space and ontological status as the narrator, and also visions, ghosts that haunt the narrator and contribute to blurring any clear distinction between self and other, life and death, reality and illusion, or past, present and future in the novel. To analyse the former and to understand the role of the latter, the concepts of characterization ${ }^{8}$ and spectrality ${ }^{9}$ prove fairly productive analytical tools.

\section{Female Characters and the Narrator's Quest for Identity}

In the 2012 electronic version of Eclipse, the novel is described as "a profoundly moving tale of a man confronting a life gone awry" (Banville n.p.). This description would insist on the centrality of Alexander Cleave, the male character and narrator in the novel and on the alleged masculinity of Banville's worlds of fiction. However, it is my contention that this centrality is also claimed by the four female characters that inhabit the novel, Alexander Cleave's mother, his wife Lydia, his daughter Cass and the foundling, Lily, who play significant roles in Cleave's process of recovery of his lost identity. ${ }^{10}$ In this respect, Derek Hand states: "Eclipse is ostensibly concerned with the plight of Alexander Cleave but, as the novel progresses, it becomes increasingly clear that the person haunting the narrative is his daughter Cass" (Exploring 170). Carol Dell'Amico has called attention to a certain shift in perspective in the Cleave trilogy, of which Eclipse is the first novel:

Although Banville's writing does not conspicuously change in the last series, the Cleave novelist does begin to acknowledge the fiction's lapses and respond to the charges of masculinism. In Eclipse Banville does this quite obviously by incorporating an overlooked feminine scholar, Cass Cleave, and her father, Alexander Cleave, who is a man of feeling rather than another of Banville's men of intellect. (112) ${ }^{11}$

Apart from insisting on the relevance of Cass Cleave as a character in the novel, Dell'Amico points to a no less significant change in the male character himself. Alexander Cleave poses as "another of Banville's men of intellect" but he eventually proves, to himself and to the reader, to be indeed a sensitive man, "a man of feeling", after a long and complex process of introspection which is hindered at times, but also driven, by the female characters that surround him not only physically but also in the form of memories or supernatural manifestations. 
When Alexander Cleave introduces himself, he does so in quite narcissistic a manner, picturing himself as a well-known attractive actor in his fifties: "Cleave is the name, Alexander Cleave, called Alex. Yes, that Alex Cleave. You will remember my face, perhaps, the famous eyes whose flash of fire could penetrate to the very back row of the stalls" (Banville 8). This self-presentation seems to characterize the narrator as a successful, confident, self-assured man who, like the historical emperor Alexander the Great, whose first name he shares, is in control of himself and bound to do big things in life: "The headlines I have made! - my favourite is the one they wrote after my first American tour: Alexander Finds New World to Conquer" (Banville 88; emphasis in original). However, Alexander's surname, Cleave, ${ }^{12}$ hints at a split self which alludes not only to the multiplicity of characters he has impersonated as a professional actor but also, and still of more significance, to some kind of internal division in the character's personality. It is Cleave himself who alludes to the oxymoronic nature of his name ${ }^{13}$ when he juxtaposes, in the same sentence, the two contradictory aspects of his personality: ${ }^{14}$ "Inside his suit of armour, however, all was not well with our flawed hero" (Banville 88).

In fact, when the reader meets the "hero", Cleave is suffering from a professional and a personal crisis as a result of which he flees from the stage in mid acting. Interestingly, when he freezes onstage, Cleave is performing as Amphitryon, ${ }^{15}$ a mythological character who "realizes that his identity has been usurped by a stranger" who wants to seduce his wife (Boxall 54). Furthermore, the line Cleave is unable to utter, "Who if not I, then, is Amphitryon?" (Banville 20; emphasis in original), is the line that Patricia Coughlan has highlighted as "the identity line" (93) in the play. Hence, Cleave's freezing on stage not only brings to the fore Amphytrion's diegetic encounter with his own self as other but also highlights the precise moment in which Cleave comes to the realization that he "is wracked by doubts as to the solidity of his own identity" (O'Connell, Narcissistic 23). ${ }^{16}$ This is an issue that he thinks he has managed to conceal from himself and from others so far by his playacting, not only on stage, but also in his ordinary life:

I think I took to the stage to give myself a cast of characters to inhabit who would be bigger, grander, of more weight and moment than I could ever hope to be. I studied oh, how I studied for the part, I mean the role of being others, while at the same time striving to achieve my authentic self ... I was not entirely what I pretended to be. It is an actor's failing. I did not tell lies about myself, exactly, but I did permit certain prominences to show through the deliberate fuzziness of my origins that were, frankly, larger than life. (Banville 36)

This life of pretence seems to have been fuelled to some extent by Alexander Cleave's need to comply with the requirements that he feels have been imposed on him by his mother, first, and by his wife, Lydia, later. On the one hand, it is Cleave's mother who names the boy after the historical emperor, a name which he does not dare change keen though he is on playing with his own and other's names: ${ }^{17}$ "I felt I could not afford to sacrifice the imperial label my mother - I am sure my father had no say in the matter - pinned on me so that I might be at least a noise in the world, though at once everyone, including my mother, went to work shortening my name to Alex" (Banville 35). This shortening of the imperial name, Alexander, to the more ordinary one, Alex, mirrors what he feels to be his inability to come up to his mother's expectations, what he refers to as "the unmeetable emotional demands of a bitterly disappointed mother" (Banville 141). On the other hand, his wife, Lydia, the daughter of a family of means who, as Cleave says, "lived in a hotel. I mean, her family home was a hotel" (Banville 33), also offers Cleave a chance to climb up the social ladder through marriage for, as he acknowledges, "Lydia seemed the one capable of concentrating sufficient attention on 
me to make me shine out into the world with a flickering intensity such that even I might believe I was real" (Banville 33). Yet, it is only Lydia who believes in Cleave's potential. He does not and, consequently, confesses that "I was compelled to invent, of course, to elaborate on myself, for how could I expect to be accepted for what I merely was in the exotic new accommodation she was offering me?" (Banville 37).

Conscious of his inferiority complex and of his feelings of not measuring up to what he has assumed to be the demands of his wife and mother, Cleave comes to the conclusion that his authentic self has been eluding him on account of so much forgery and is buried underneath too many masks: "[s]o you see: it was all a lie, all a part I was playing, and playing badly, at that" (Banville 141). Hence, only by abandoning his profession and escaping from his everyday life may he be able to "cease from performing and simply be" (Banville 46; emphasis in original).

In pursuit of this goal, Cleave retreats to the house by the sea where he lived as a child to be alone and, free from any other distraction, to search for a communion with his lost true self, which he believes can be tracked down from the memories of his past. Nevertheless, at the very start of his retirement, Cleave becomes aware that being alone in that house is an utterly impossible endeavour: "How could I have thought I could stay here, all alone?" (Banville 4), he says, for, as he remembers: "the place was always haunted, I spent my childhood among alien presences, ghostly figures" (Banville 49). In fact, no sooner has he got in touch with the house and its surroundings than he starts to feel "an extra weight ... as if someone had fallen silently into step beside me, or inside me, rather" (Banville 3) and to be visited by what he calls an "image, vision, hallucination" which he describes as "the figure of a woman, tall, young, turning from the range, abruptly handing something, it looked like, to what seemed a seated child" (Banville 43).

The motifs of the ghost and the uncanny house are recurrent in Irish literature and folklore as manifestations of the supernatural since "[b]elief in the supernatural has been an integral part of the world view of the Irish people over many centuries" (Lysaght 1). In fact, ghosts are perceived as ordinary. Hence, when Alexander Cleave refers to his being visited by what seems to be the ghost of a woman and a child, he says: "What struck me first about the image, vision, hallucination ... that I glimpsed out there was the ordinariness of it" (Banville 43). Cleave is neither scared nor shocked because "[i]t was not the first time I had seen a ghost in this house" (Banville 44). As he remembers:

One day, when I was a boy, in the dreamy boredom of a summer afternoon I climbed up the unlit steep stairs to the garret, drawn there at who knows what behest ... when something, not a sound but a sort of tightening in the atmosphere of the room, made me turn my head. I expected it would be one of the lodgers ... But it was not a lodger. It was my dead father, standing in the open doorway, as real as in life, dressed in striped pyjamas and shoes without laces and an old wheat-coloured cardigan, the same attire that he had worn every day in the long last months of his dying. (Banville 44)

Apart from the normality with which the narrator refers to the ghost of his father, it is interesting to notice that Cleave endows the living and the dead with the same ontological status since they may be easily confused. In fact, when he alludes to the "ghostly figures" among which he spent his childhood, he not only thinks about the dead, who seem to be as real to him as when they were alive, but also about the living. ${ }^{19}$ Lodgers were perceived by the child as presences without real entity, ethereal figures without a purpose who, consequently, although physically alive, counted as metaphorically dead to him: "How meek they were, our lodgers, how self-effacing, blurring themselves to a sort of murmur in the 
house. I would meet them on the stairs, squirming sideways as they edged past me and smiling their fixed smiles of pained politeness. At night I would seem to hear their presence all around me, a tossing, a shifting, a low, restless sighing" (Banville 49-50). Interestingly enough, the adult Cleave recognises himself in them, since, like them, he no longer seems to have any purpose in life, and is also metaphorically dead, a living ghost: "Now, here I am, a lodger myself, no more real than the phantoms that appear to me, a shadow among insubstantial shadows" (Banville 50).

Joseph McMinn alludes to "a calculated 'Gothic' strain" in Banville's narrative fictions, which he describes as "the sense of living in a haunted place, being observed by the ghosts of the past" ("Plethora" 137). Alexander Cleave believes that by going back to his haunted house and tracking down his past will he be able to come to terms with his present. As he says, "The house itself it was that drew me back, sent out its secret summoners to bid me ... home, I was going to say" (Banville 4; emphasis in the original). Thus, he firstly starts exploring the house, looking for any remnant of his childhood: "Grimly I mounted the steps as if I were climbing into the past itself, the years pressing down on me like a heavier atmosphere. Here's the room looking out on the square that used to be mine. Alex's room" (Banville 17-18). Yet, far from getting any answer there, Cleave soon realizes that "[e]verything in the room seemed turned away from me in sullen resistance, averting itself from my unwelcome return" (Banville 18). And, later on, almost at the end of his narrative, he acknowledges his mistake when he says: "I was looking the wrong way, I was looking into the past, and that was not where those phantoms were from, at all" (Banville 208).

In her study The Spectral Metaphor: Living Ghosts and the Agency of Invisibility (2014), Esther Peeren points out that "[a]lthough ... elaborations of spectrality are methodologically distinct and vary in the characteristics, functions and effects they assign to the central concept, they do share certain interrelated emphases" (10). According to Peeren, spectrality understands the ghost in at least three different ways: first, "the ghost as a figure of return, capable of expressing the persistence of the past in the present" (10); second, "the ghost as a present absence: despite being ephemeral, something is there that matters and has to be taken into account" (10; emphasis in original); and third, "the ghost potency as a critique of the 'unmixed', of 'what is somehow pure and self-sufficient or autonomous, what is able to be disengaged from the general mess of mixed, hybrid phenomena all around it and named with the satisfaction of a single conceptual proper name" (10). In Eclipse, the grown-up Cleave has to cope with at least two different forms of ghosts, which would correspond to Peeren's first two concepts and which, as has already been suggested, would have distinct but complementary functions in his development. Once that any ontological distinction between the living and the dead has been blurred in the novel, it could be safely affirmed that, on the one hand, the narrator's mother and his wife, Lydia, who belong to Alexander Cleave's past, would stand for what Peeren defines as "the ghost as a figure of return, capable of expressing the persistence of the past in the present". On the other hand, Cleave's daughter, Cass, and the unexpected foundling, Lily, who, unknown to him, has been living in the house with his father, Quirke, as squatters for some time, would stand for what Peeren defines as "the ghost as a present absence", that is to say, something "that matters and has to be taken into account". Having already dealt with the role that Cleave's mother and his wife have as ghosts of the past, it is Peeren's second category, the ghost as a present absence, that has yet to be analysed and, with it, the two other female characters in the novel, who trigger the significant change the narrator undergoes by the end of the story.

It is my contention that, free from the ghosts of the past, Alexander Cleave disrobes himself of what he acknowledges to be "this hideous awareness, this insupportable excess of self" (Banville 50) and adopts instead "an attitude of open expectancy" (Peeren 11) that includes and accepts the existence of the other within the self, as different from the self, no 
matter its obscure or weird provenance. ${ }^{20}$ This is where the idea of the ghost as present absence comes into play. In her study, Peeren focuses on what she calls the living ghosts, that is to say groups of people who "are frequently - sometimes to the point of cliché - likened to ghosts or related figures, on the basis of their lack of social visibility, unobtrusiveness, enigmatic abilities or uncertain status between life and death" (5). This idea may be easily extrapolated to the figure of Cass, the narrator's "invisible" daughter, but also to Lily, an outcast who lacks social visibility and finds refuge inside the house. According to Esther Peeren, the ghost as a present absence, or living ghost,

emerges as a figure of radical alterity, ... underpinning an ethics of intersubjectivity in which the self rather than negating or assimilating the other, is asked to adopt an attitude of open expectancy striving for the ideal of absolute hospitality, which welcomes without imposing conditions. The ethics is presented by Derrida as the path to 'learn[ing] to live finally' in a more just and responsible manner, in relation to oneself and one's own inevitable death as well as to the other. (11)

Cass Cleave and Lily emerge as "figures of radical alterity" in the novel. They both force themselves into the narrator's life and turn this self-absorbed man into "the ideal of absolute hospitality", a "man of feeling" who eventually learns to live "in a more just and responsible manner". In fact, when Cleave begins to experience the uncanny form of invasion which has been previously alluded to, he is not revolved by this act of possession but, on the contrary, welcomes this "someone who was else, another, and yet familiar" (Banville 3) because, by accepting this other inside himself, he feels that he is bound to achieve the wholeness he has been looking for, to be reunited with the part of him that is missing, that which he lacks.

The weight the narrator experiences is directly associated in the novel with his daughter Cass, who has always been a source of anxiety to him and who also seems to be going through a difficult personal situation. Cass seems to have no real presence in Cleave's narrative, she is just talked about by the narrator in a fairly patronizing manner that hides her actual intellectual capacities behind an indeterminate mental instability which her father euphemistically refers to when she calls her "our poor damaged daughter" (Banville 205). Besides, it is not until quite late in the story, once that Cass's pregnancy has been revealed and she is known to have committed suicide, that the narrator makes the connection between "our difficult daughter" (Banville 42) and the figure of a woman with a child that has been haunting him in the form of dreams, visions or ghostly apparitions. However, Cass, as a living ghost, is an active present absence that insists on being taken into account and that, as a consequence, can be read not only as a figure of dispossession (in line with many of the previous female characters in Banville's fiction) but also, and more importantly, as a figure of empowerment who eventually forces the reader to revise the narrator's diminishing comments about her from a new perspective, an ironic distance that eventually confronts Cleave with his tragically wrong perceptions of his daughter as both a human being and a scholar, as well as with his absolute failure as a father, ${ }^{21}$ for as he himself acknowledges:

Did I love my daughter, try to wean away from her darkest obsessions, save her from her worst excesses? Not I: she was a trial to me, an irritation, a tumbling block on the road to stage success, a source of shame and embarrassment before my smart friends in the brittle make-believe world in which I was trying to claw my way to fame. (Banville 141)

The strong uncanny connection between Cleave and his daughter is made evident when the narrator uses a specifically feminine symbol in order to describe his impossibility to be alone: 
"I still felt invaded, as I had that day out in the fields: invaded, occupied, big with whatever it was that has entered me. It is still here; I feel I am pregnant; it is a very peculiar sensation" (Banville 15; emphasis added). Challenged by the presence of this unknown other, the narrator's body seems to undergo a process of feminization that finds its ultimate expression in the metaphor of pregnancy, which establishes the final link between himself and his daughter, who is actually pregnant with a real child. ${ }^{22}$ This process of feminization reflects to a certain extent Cleave's process of completion: "Before, what I contained was the blastomere of myself, the coiled hot core of all I was and might be. Now, that essential self has been pushed to the side with savage insouciance, and I am as a house walked up and down in by an irresistibly proprietorial stranger"23 (Banville 15; emphasis added).

In Eclipse, the house challenges the narrator's sense of self and truth by bringing together the dead and the living, the past and the future, reality and the workings of the mind. ${ }^{24}$ Especially relevant in this respect is the following fragment of the novel in which Cleave, who is coming back from a stroll in the fields adjacent to the house, looks up and sees the shadow of a woman behind a window, who is looking at him and whom he takes to be Lydia, his wife:

I turned and looked back at the house and saw what I took to be my wife standing at the window of what was once my mother's room. The figure was motionless, gazing steadily in my direction but not directly at me. What did she see? What was it she was seeing? I felt diminished briefly, an incidental in that gaze, dealt, as it were, a glancing blow or blown a derisive kiss. Day reflecting on the glass that made the image in the window shimmer and slip; was it she or just a shadow, woman-shaped? I set off over the uneven ground, retracing my steps, with this other, my invader, walking steadily inside me, like a knight in his armour. (Banville 3)

The fragment is worth quoting in full because, as I intend to explain, the narrator's mistake as to the woman in the window being his wife Lydia allows for the symbolic gathering in the same paragraph of all the female figures that visit the house and keep on intruding in the process of introspection the narrator aims to fulfil: Lydia, the narrator's mother, Cass, and Lily.

It is my contention that the narrator's mistake in taking Lydia to be the woman in the window functions as a tool to visually relate his wife to his dead mother. For a start, the place the supposed Lydia is standing in is what was once the room of the narrator's mother. Bearing in mind that a significant amount of narrative time is dedicated to the depiction of the narrator's special sensibility that connects him to the dead, as exemplified by the vision of his dead father (Banville 44), for instance, Cleave's ruminations and unclear perceptions suggest that the shimmering, slipping image in the window could very well be the ghost of his mother, which he has been conjuring up from the start and wondering "[w]hy is it not she who appears to me?" (Banville 59). Confusing his wife with his mother is something that does not shock the reader because, on the one hand, Cleave has an Oedipal relationship with his mother and, on the other, he perceives Lydia more often than not in the role of a mother rather than in that of a wife. For instance, it is Lydia who accompanies him, or rather, drives him when he decides to move to his mother's house; she scolds him as she would a child; she adopts a patronizing attitude towards him; and, as Cleave says at one point, "[s]he took care of me, protected me from the world, and from myself" (Banville 39). Besides the image the narrator has of Lydia and of his mother is that of two strong women -"I know that of the two of us she [Lydia] was the stronger" (Banville 39)- who are also big in size, not only physically but also symbolically, to the extent that in the presence of these two women, the narrator feels somehow intimidated. This is evident when Cleave describes his mother in the final years of 
her life as "no longer human, she seemed something more than that, ancient and elemental" (Banville 60); or when he describes Lydia as "a big-shouldered, handsome woman ... She is as tall as I am, even though it seems to me I can remember a time when I had a good hand's span on her. Perhaps I have shrunk, it would not surprise me. Misery is a certain shriveller" (Banville 7). The narrator goes so far as to establish a perverse, morbid connection, imbued with sexual connotations, between the body of his ill mother and that of his wife: "She [Alex's mother] was warm and flaccid and faintly atremble, and I was shocked to find myself thinking of Lydia as she would be at the climax of love-making" (Banville 59). Yet, as has already been signalled, mother and wife remind the narrator of what he has not achieved in life and, consequently, belong to the old, wasted world, the world of pretence and failure that Cleave needs to leave behind if he is to regain his true self.

However, the analysis of the woman in the window is far from complete yet. For, even though the fact that the woman Cleave sees is framed by a window ${ }^{25}$ would immediately transform her into an object to be looked at, she, on the contrary, is posited as the seeing agent, and, momentarily at least, occupies the authoritative place of the male narrator, who subsequently becomes the object of the female gaze. This reversal is achieved doubly. Firstly, through the visual depiction of the scene -with the woman, who occupies a high position, looking down on the narrator- a high angle shot, which is normally used in cinema to make the subject vulnerable or powerless. And, secondly, through the character's simultaneous acceptance of his feeling at the time "diminished briefly, an incidental". I, therefore, agree with Ghassemi in that, "Alex seemingly loses the privileged position of the male gazer, and instead, is reduced to the object that embodies what Mulvey calls "to-be-looked-at-ness"" (215). However, I disagree with him when he says that this reversal has no subversive potential. Ghassemi says "[p]ositing Lydia as the seeing agent is in fact a ploy on Alex's part in order to maintain the other's function as a spectacle, or a mirror, for his own narcissism" (215). In my view, Ghassemi falls into the same trap the narrator does and takes this woman to be Cleave's wife, Lydia, when in fact, there are several clues in the narrative that lead the reader to the conclusion that the mysterious woman in the window is in fact Lily.

The most significant of these clues is that Lily is the only female character who has an outstanding position as a true bearer of the gaze in the novel. Apart from the ghost that haunts the narrator, Cleave also has "the feeling" of "being observed by living eyes". Before learning that Lily is living in the house with her father and that it is Lily who spies on him, the narrator says: "Last evening when I was doing my washing at the kitchen sink I turned my head quickly and caught sight of something in the doorway, not a presence but an intense absence, the vacated air quivering where a second ago I am convinced someone more substantial than a ghost had been standing, watching me" (Banville 54; emphasis added). The fact that Lily is the actual bearer of the gaze inside the house identifies her with the woman in the window who is also watching him.

Then, the narrator realises that "someone had been sleeping in my mother's bed" (Banville 18) and, as he decides to explore the house, he discovers that that someone is no other than Lily, a discovery that physically identifies her again with the woman in the window.

Lily even spies on the narrator's erotic dreams, which exemplify the kind of voyeuristic gratification the male gets from watching two women having sex: "Languorously my fancy found its way back to the woman in the dream and traced again the outline of her white limbs and touched her secret places, but without agitation now, curious only, mildly wondering at the unreally white flesh, the fantastical lewdness" (Banville 26). Yet, Lily refuses to play the role of erotic object in a male dream something that causes the narrator's confusion as to her gender: "Musing thus in drowsy torpor I turned my head on the pillow and it was then I saw the figure in the room, standing motionless a little way from the side of the 
bed. I took it for a woman, or womanish old man, or even a child, of indeterminate gender" (Banville 26). Lily faces him and, as a result, occupies again the position of the authoritative bearer of the gaze, who is metaphorically presented as a guardian of the sickroom: "Shrouded and still it stood facing in my direction, like one of those guardians of the sickroom long ago, the dim attendants of childhood fevers" (Banville 26).

Unlike other women in Banville's fiction, in Cleave's own words, Lily "has upset the balance of things. My phantom woman and her more phantasmal child were quite enough without this all too corporeal girl to dog my things" (Banville 95). Lily puzzles the narrator who sees her as "an animate riddle that I have been set to solve" (Banville 123) and who openly asks himself "[w]hat am I to do about this girl, this Lily? She preys on my mind" (Banville 95). Cleave frequently refers to Lily as a "surrogate daughter" (Banville 157) and instinctively compares Lily with his daughter, Cass: "She reminds me of Cass, naturally ... They could not be more different, in almost all ways, ... and yet there is something essential that is common to them both ... something deeper than a look, that makes me tolerate this invasion of my solitude" (Banville 96). He even fantasises with adopting her, now that his real daughter has turned into a woman and, as he affirms, "[a] woman can't be a daughter" (Banville 137). Still a child in many respects, Lily may be read as the emergent child, the child in forming whose vision has been haunting the narrator alongside the ghost of his daughter Cass. Yet, although Cass has been mostly an absence, a void in the narrator's life, "so caught up in himself has he been" (Hand, Exploring 170), Lily is there, fully present and ready to devour life. Cleave plans "to give her the house. I hope she will live here. I hope she will let me visit her" (Banville 213) and dreams of a future with her: "I have all kinds of wild ideas, mad projects. We might fix up the place between us, she and I ... Why, we might even take lodgers again!" (Banville 213). Lily is undoubtedly the narrator's second chance as a father. In fact, no sooner has he finished voicing his projects for the future with Lily that Cleave receives the final visit from the ghost of Cass, who is now dead: "Cass! ... I reached a faltering hand to touch her, and I spoke her name, and she seemed to pause and shiver, as if she had indeed heard me, and then at once she was gone, leaving only the glistening chord of her passing, that faded, and fell. ... I turned to the room again and there Lily was" (Banville 214). According to Molly Elizabeth Ferguson, "a ghost appears where there is a space left by loss, inhabiting the absence until it is properly grieved and understood" (6). By the end of the novel, Cass, who has been a loss, an absence in the narrator's life is properly grieved and understood by her father who decides to write about his daughter's story from a new angle. ${ }^{26}$

\section{Conclusions}

When I searched inside myself I found nothing finished, only a permanent potential, a waiting to go on. At the site of what was supposed to be my self was only a vacancy, an ecstatic hollow. And things rushed into a vacuum where the self should be. Women, for instance. They fell into me, thinking to fill me with all they had to give. It was not simply that I was an actor and therefore supposedly lacking an essential part of personality; I was a challenge to them, to their urge to create, to make life. I am afraid they did not succeed, with me. (Banville 33)

This paragraph is one of the best examples in the novel of the apparently irreconcilable binary opposition the narrator claims to exist between himself, the male central voice in the story -no matter how vacant or hollow-, and his "essential other", women, nurturing figures who, in his view, are attracted by him because they possess what he lacks, "an urge to create, to make life". ${ }^{27}$ Driven by his apparent sense of superiority, Alexander Cleave claims to be a challenge to them and affirms their sustained failure in their attempt to fill his vacant, hollow self. 
Ironically, however, by the end of the novel, the reader realises that, contrary to what would be expected from Banville's presumed masculinism and despite the apparent centrality of the male narrator, it is women, who challenge the narrator's world and female agency, in its different, sometimes uncanny manifestations, that guides his search for identity, changes his perception of reality, and, contrary to what he claims when he affirms that "I am afraid they did not succeed with me", proves to be quite successful in offering him a second chance to be redeemed from his past mistakes and start anew.

In this sense, Cass and Lily are the most challenging female characters in Eclipse. When Alexander Cleave ponders about the nature and cause of the woman with child haunting him, he comes to the following conclusion: "The suggestion of the familial the phantoms bring with them makes me wonder if they might be the form of a rejected life coming back to claim me. After all, here I am, living in the house of the dead" (Banville 49). This comment is one of the keys to the novel, since Cass's ghost is precisely the form of a rejected life coming back to claim the role she deserves as both woman and scholar. Cleave's response and his attempt at atonement is the writing of this book, in which Cass turns out to be the most significant silent presence and a figure of empowerment that returns Cleave his creative potential. As Robin Wilkinson says in this respect, "in the tale of an actor, identity is performance and, when Cleave's own mask slips, the familial figures of a repressed drama come to the fore, allowing the reader to glimpse into the wings of the creative process. The voice that emerges from behind the actor's fragmented personae belongs to an authorial figure whose confession resuscitates the genesis of a novel" (356).

For her part, Lily is the flesh and blood character, the child who manages to eventually fill the narrator's existential void and who restores him with his lost identity as both an individual and a father, as is made explicit in the scene at the circus in which Lily volunteers to participate in one of the performances that involves Cleave's alter ego George Goodfellow. There, fearing the possibility of losing Lily to Goodfellow's will, Cleave stands up and says: "'My name is Alexander Cleave,' I said, in a loud, firm voice, 'and this is my daughter"” (Banville 187).

In the temporal organization of the narrative, Cleave's uttering these identity words roughly coincides with the natural eclipse, already made prominent in the title of the novel, and with the actual moment of Cass's suicide, the traumatic event that generates the story Cleave writes in a small room of his childhood home. ${ }^{28}$ Lily and Cass, Cass and Lily are, consequently, the female characters that allow Alexander Cleave to find his identity as an individual, as a father and as a creator.

\section{Notes}

\footnotetext{
${ }^{1}$ This ratio has almost doubled in the past ten years. On the one hand, Banville has published four novels in that time span; on the other, since 2006, he has produced nine works of crime fiction using the pen name Benjamin Black.

${ }^{2}$ In a conversation with Derek Hand on account of the publication of the special issue of the Irish University Review, Banville acknowledged: "The thing that interests me in the novel is voice. I consider myself to be in the oral tradition - that might strike people as rather strange, I suppose. In fact, all Irish writers have something of that oral tradition in their blood. ... I'm not interested in politics, I'm not interested in society, I'm not interested in Man. I seem to be just interested in this voice that goes on and on in my head" (Friberg, "Conversation" 201). Apart from the author himself, two of his most relevant critics, Derek Hand and Joseph McMinn, call attention to the importance that voice has in Banville's fiction and relate Banville to Beckett in this respect. Hand remarks that "Beckett increasingly retreats toward the singular voice" and so does Banville (Exploring 15). McMinn points out that "both writers have created a body of fiction which depends utterly on the drama of the voice, a consciousness which feeds off its own imagination and memory, and which consoles itself with its own fictions" (Supreme 162).
} 
${ }^{3}$ In his article "The Empathic Paradox", Mark O'Connell analyses Shroud and The Infinities as two telling examples in which Banville abandons the first-person confessional narrative in an attempt to make his narrators "transcend their narcissism and advance towards a more empathic, less self-centered position in relation to others" ("Empathic" 428). However, as he explains, "where his novels switch to a third-person perspective ... the narration itself becomes highly problematic" (428).

${ }^{4}$ Hedwig Schwall says that Banville's narrators are "prototypes who agonize over their identity or rather over the lack of it" (116).

${ }^{5}$ Talking about his literary influences, Carol Dell'Amico has signalled that "Banville's copiously plundered material - tropes, scenes, and voices - is adapted from canonical predecessors who reached their peak before or by midcentury, including Henry James, James Joyce, Thomas Mann, Samuel Beckett, and Vladimir Nabokov, and it draws variously on romanticism and modernism, and on theatrical and plastic traditions" (108). Significant criticism has also been produced on the artistic allusions in Banville's novels, among which the following ones should be mentioned: Laura P. Z. Izarra's "Disrupting Social and Cultural Identities: A Critique of the EverChanging Self” (2006); John Kenny's “Well Said Well Seen: The Pictorial Paradigm in John Banville's Fiction" (2006) and chapter 6 of his monograph John Banville (2009); Neil Murphy's "From Long Lankin to Birchwood: The Genesis of John Banville's Architectural Space" (2006); and Marta Cerezo Moreno's "Returning Home versus Movement without Return: A Levinasian Reading of John Banville's The Sea" (2015).

${ }^{6}$ For an exhaustive analysis of intertextuality in this novel, see Robin Wilkinson's article "Echo and Coincidence in John Banville's 'Eclipse'" [sic] (2003). Wilkinson not only provides a profuse inventory of the intertextual references that are voiced by the narrator, to whom he refers as "something of a vulture culture" (365). He also suggests that, in bringing together those allusions, Banville, on the one hand, "unites Maria Edgeworth and James Joyce, and gives voice to the divided native tradition, the Anglo-Irish and the Irish" (366), and, on the other, provides a "real answer in the debate about whether he belongs to an Irish or European tradition" (367).

${ }^{7}$ According to Elke D'hoker, "Banville's conception of the self as plagued by solipsism and self-consciousness is to a large extent indebted to Beckett. Both writers also express both the need and failure to transcend the borders of the self" ("Self-consciousness" 79). Likewise, John Kenny has pointed out that Banville's "view that Beckett, in contrast to Joyce, 'threw everything out', fed into Eclipse (2000), a novel that, after The Untouchable, the longest in the oeuvre, returned Banville to an even less sequential and plot-less form of fiction than he had written before in the trilogy" ("Pictorial" 55).

${ }^{8}$ For a theoretical approach to the narratological concept of characterization, see, Shlomith Rimmon-Kenan (1973), Mieke Bal (1985) or Jeremy Hawthorn (1997).

${ }^{9}$ The field of spectral studies can be located in the decade of the 1990s and has "evolved from a supernatural phenomenon, mainly technological metaphor into a concept -spectrality- adopted as an analytical tool throughout the humanities and social sciences" (Peeren 9; emphasis in the original). The term spectral turn, on the other hand, is a more recent phenomenon, “introduced in 2002 by Roger Luckhurst, who considers Derrida's 1993 Spectres de Marx ... its catalyst" (10-11).

${ }^{10}$ Although there is still another female character in Eclipse, Dora, I do not list her here because she does not have a relevant role in the narrator's quest for identity but is rather presented as a mundane object of desire in Alexander Cleave's story. The narrator introduces her as "my first manifestation of the muse" (Banville 84) and describes her as an erotic, carnal object: "I recall her provocatively meaty smell, which even the strongest perfume could not entirely overcome ... and although she cannot have been more than thirty she seemed immensely old to me, excitingly so, a sort of inverted mother, carnal and profane" (84). Dora is, then, but an erotic memory in Cleave's narrative.

${ }^{11}$ The father-daughter relationship in Eclipse is retaken in Benjamin Black's Quirke Series, a set of crime fiction novels that Black began to publish in 2006 and whose storyline involves Quirke -a name that echoes that of one of the male characters in Eclipse- and his daughter Phoebe, who has a prominent role in the fiction. In Dell'Amico's words, "the highly successful work of Benjamin Black has not only secured for its author a prominent place among the current writers of Irish crime fiction, but it also invites intertextual analysis as a form of engagement both with Banville's earlier work and with those critics who have viewed negatively the author's articulation of questions of gender in the novels" (106).

${ }^{12}$ The choice of names in Banville's fiction is always an element to take into serious consideration. In an interview with Hugh Haughton and Bryan Radley on account of the publication of Ancient Light, Banville said "I think every novelist knows this, that once you've got the names, you've got the thing beaten; you've wrestled it to the ground. And when I used to review fiction, which I don't really do anymore, I could get a novel in the first ten pages. If the names were wrong, I'd know that the rest of the book was going to be wrong as well, because somehow the novelist hadn't blended with his material" (858). Naming is, thus, an important part of the process of characterization in Banville's fiction. Eclipse is no exception in this respect. For a detailed analysis of the names of the main characters in Eclipse, see Wilkinson 2003. 
${ }^{13}$ Hedwig Schwall has called attention to the fact that "Banville's figures are all split: they are actors, spies, or (often paranoiac) researchers looking for their lost twin. But it is not only their profession which indicates their split condition, their names also reveal a heterogeneous nature ... or contain blatant oppositions ... Cleave, finally, indicates the very split itself' (116).

${ }^{14}$ According to Mark O'Connell, Alex Cleave's split personality makes of him a perfect example of what he describes as Banville's "self-obsessed narcissist" (Narcissistic 23): "Narcissists are those ... who vacillate between excessive self- aggrandisement and feelings of utter worthlessness and meaninglessness" (O'Connell, Narcissistic 6).

${ }^{15}$ Robin Wilkinson (2003), Peter Boxall (2009) and Mark O'Connell (2013) have called attention to the fact that, in O'Connell's words, “though it is not specified whether it is Kleist's 1808 version of Amphitryon that constitutes Cleave's disastrous final performance, it seems reasonable to assume that Banville had it in mind, given that around the time he was writing Eclipse he was also engaged in writing the play God's Gift, a version of Kleist's comedy Amphitryon set in his native Wexford during the 1798 rebellions" (Narcissistic 23). Thus, it is Kleist's Amphitryon, with its focus "on inhabitation and possession" and its "fascination with multiple identities", that "makes ... such a resonant intertext for Banville" (Boxall 54). Wilkinson goes a step ahead when he explains that "[i]n Eclipse, Amphytrion's question [who speaks if not I?] is cued, framed, and repeated in such a manner as to place selfhood and intertextuality at the heart of the novel" (366). Banville's fascination with Kleist's Amphitryon was also present in his conversation with Derek Hand. When asked whether there would be a sequel to what was his last novel to date, The Sea, Banville said: "I think what I'm going to write next is a novel based loosely on Heinrich von Kleist's Amphitryon" (Friberg, "Conversation” 212).

${ }^{16}$ Derrida's concept of différance is very suitable to explain Cleave's instability of identity, as Ulla Kerren has pointed out in an interesting work which also analyses the identity of the male protagonist of John Banville's Eclipse using "Jacques Lacan's ideas about the mirror stage and the Oedipal crisis as well as about the imaginary and the symbolic order" (5).

${ }^{17}$ Alexander Cleave changes the names of the two female members of his family. He explains the reason why he renamed his wife from Leah into Lydia thus: "I should say in fact that my tender-eyed wife's real, or given, name is Leah; ... when I was introduced to her I misheard it as Lydia, and when I repeated it later she liked it, and we kept it between us as a love-name, and eventually it became established, even among the more easygoing members of her family" (Banville 35). The change of names in the case of his daughter is just mentioned, not explained: "Catherine is her name. We call her Cass" (Banville 81).

${ }^{18}$ From that moment on, Cleave makes of his marriage and his family life a theatrical performance of which his attending the birth of their daughter is but another example: "I was present for the birth - oh, yes, I was very progressive, went on for all that kind of thing; it was another performance, of course, inwardly I quailed before the bloody spectacle" (Banville 41).

${ }^{19}$ This juxtaposition of the living and the dead is a recurrent feature in Eclipse.

20 "Freud's inventory of motifs of the uncanny is one of Banville's favourite tools to structure a story, but in this exercise he seems to aim beyond psychoanalysis, to a more complex, Deleuzian fragmentation of the subject" (Schwall 121).

${ }^{21}$ Alexander Cleave comes to the realization that he has failed as a father with regard to Cass because he has never seen her as an independent being. He has mostly seen her as a projection of himself, almost as his alter ego. In fact, the reader recognizes Alex in quite a few of the descriptions he makes of Cass. "In narrating Cass, her father's voice, in Eclipse, becomes exasperated and bewildered: 'There was no keeping track of her moods, I never knew when she might veer aside and turn and confront me with a new version of herself, a whole map of that strange, intense and volatile world that she alone inhabits. For that is how she makes it seem, that she lives in a place where there is no one else' (p. 71). He wonders whether she might be acting, feigning new sides of herself" (Friberg, "Rites" 154).

${ }^{22}$ Robin Wilkinson relates the metaphor of paternal pregnancy to a much more complex, controversial issue: incest. In Wilkinson's words, Cleave "claims a special, exclusive relationship with Cass, as if the union of child and mother lived on in his fantasy of himself as maternal figure: 'When they lifted Cass away from me, I seemed to hear the twang of an umbilical cord, one that I had paid out of myself, severing' (p. 42). Like the fusion of mother and son, this birth scene contains the ominous association of birth and death. The story of parenthood and bereavement involving father and daughter constitutes the first and most obvious plotline of the novel but it is frequently overwhelmed by the scenes and visions that invade the house - fantasies of paternal pregnancy and birth-giving, talk of incest between a 'madwoman in the attic' and her father next door, allusions to Jupiter and his favoured daughter Minerva. The insistent underlying scenario is that of the adored daughter standing in for the dead mother in an exclusive relationship between father and offspring" (360).

${ }^{23}$ This comparison between himself and a house being inhabited by a stranger works as a metaphor for what Elke D'hoker describes as "small and momentary manifestations of alterity" (Visions 219) which usually happen in Banville's fiction when the male narrator is forced to face the other. As D'hoker suggests: "The terror the 
other usually inspires, is due to its power to challenge the self out of itself, out of its secure environment, steady convictions and subjective opinions ... the other dangerously confronts the self with its own limits, as human knower and as human being, so that the presence of the other always threatens to bring about the absence of the self' (Visions 217). In Eclipse, however, the presence of the other fills in the absence in the self.

${ }^{24}$ Alex Cleave's delusional experiences may be read as a result of the traumatic experience of having lost her daughter. As Wendy O'Brien argues, "[t]he novels of writers such as Pat Barker, John Banville, and Anne Michaels rely on ghost stories, doppelgangers and unreliable narrators in order to capture something of the time of trauma. Using these techniques, their works capture a past that won't stay past and a future that won't come into vision. They write in and of an altered sense of time" (210-211).

${ }^{25}$ Studying place in John Banville's novels, Kersti Tarien Powell explains that "[w]indows constitute a threshold between the outside world and the interior space, connecting the two and allowing the perceiving agent to frame the world ... spatial relations extend to encompass the self, that is, place and window essentially function as sites of self-projection" (39) and argues that "framing is also an integral part of the formation of self-identity" (44).

${ }^{26}$ The second novel of the Cleave trilogy, Shroud (2002), does exactly this.

${ }^{27}$ Mehdi Ghassemi argues that "the protagonists' obsession with finding the true nature of their self and reality is seemingly intertwined with the mystery of femininity ... Women in Banville's fiction embody the 'essential other' as they appear to possess what the narrators 'lack"' (206).

28 "Survivors seek not to escape so much from the past as they hope to escape into a future. And it is for this reason that those who suffer trauma turn to literature ... Literature ... allows for and is able, at its best, to capture something of what Alice Miller describes as the 'episodic structure of memory' (2000, 17), which those who suffer trauma are left with. As such, literature is a point of contact, or a meeting place in which the traumatic and the commonplace can encounter each other without attempting to reduce the one to the other" (O'Brien 218).

\section{Works Cited}

Bal, Mieke. Narratology: Introduction to the Theory of Narrative. Toronto: University of Toronto Press, 1985.

Banville, John. Eclipse. London: Picador, 2000.

Boxall, Peter. Since Beckett: Contemporary Writing in the Wake of Modernism. London and New York: Continuum, 2009.

Cerezo Moreno, Marta. "Returning Home versus Movement without Return: A Levinasian Reading of John Banville's The Sea". ATLANTIS. Journal of the Spanish Association of Anglo-American Studies 37.1 (June 2015): 51-68.

Coughlan, Patricia. "Banville, the Feminine, and the Scenes of Eros". Irish University Review 36.1 (Spring-Summer 2006): 81-101.

D'hoker, Elke. Visions of Alterity. Representation in the Works of John Banville. Amsterdam: Rodopi, 2004.

"Self-consciousness, Solipsism, and Storytelling: John Banville's Debt to Samuel Beckett”. Irish University Review 36.1 (Spring-Summer 2006): 68-80.

Dell'Amico, Carol. “John Banville and Benjamin Black: The Mundo, Crime, Women”. ÉireIreland 49.1-2 (Spring-Summer 2014): 106-120.

Ferguson, Molly Elizabeth. The Ghost in the Irish Psyche: Ghost Stories in Contemporary Irish Literature. $\mathrm{PhD}$ thesis. University of Connecticut, 2010.

Friberg, Hedda. "“[P] assing through Ourselves and Finding Ourselves in the Beyond': The Rites of Passage of Cass Cleave in John Banville's Eclipse and Shroud'. Irish University Review 36.1 (Spring-Summer 2006): 151-164.

"John Banville and Derek Hand in Conversation". Irish University Review 36.1 (Spring-Summer 2006): 200-215.

Ghassemi, Mehdi. Precarious Subjectivity in the Works of John Banville: A Lacanian Reading. PhD thesis. Université Charles de Gaulle - Lille III, 2015.

Hand, Derek. John Banville: Exploring Fictions. Dublin: The Liffey Press, 2002. 
“John Banville’s Quixotic Humanity”. Irish University Review 36.1 (Spring-Summer 2006): viii-xii.

Haughton, Hugh and Bryan Radley. "An Interview with John Banville". Modernism / Modernity 18.4 (November 2011): 855-869.

Hawthorn, Jeremy. Studying the Novel. An Introduction. London: Edward Arnold, 1992.

Izarra, Laura P.Z. "Disrupting Social and Cultural Identities: A Critique of the Ever-Changing Self". Irish University Review 36.1 (Spring-Summer 2006): 182-199.

Kenny, John. "Well Said Well Seen: The Pictorial Paradigm in John Banville's Fiction". Irish University Review 36.1 (Spring-Summer 2006): 52-67.

- John Banville. Dublin \& Portland: Irish Academic Press, 2009.

Kerren, Ulla. "I Really Am a Stranger to Myself": A Lacanian Reading of Identity in John Banville's Eclipse. Masters thesis. Linnaeus University, 2012. 9 October 2017. http://www.diva-portal.org/smash/record.jsf?pid=diva2\%3A536845\&dswid=-1578

Lysaght, Patricia. "Traditional Beliefs and Narratives of a Contemporary Irish Tradition Bearer”. Folk Beliefs Today. Eds. Mare Kõiva and Kai Vassilijeva. 12 October 2017. e-version Tartu, 2001/2002. http://www.folklore.ee/rl/pubte/ee/usund/ingl/lysaght.html

McMinn, Joseph. The Supreme Fictions of John Banville. Manchester: Manchester University Press, 1999.

—. "“Ah, this Plethora of Metaphors! I Am like Everything Except Myself': The Art of Analogy in Banville's Fiction”. Irish University Review 36.1 (Spring-Summer 2006): 134-150.

Murphy, Neil. "From Long Lankin to Birchwood: The Genesis of John Banville's Architectural Space". Irish University Review 36.1 (Spring-Summer 2006): 9-24.

O'Brien, Wendy. "Telling Time: Literature, Temporality and Trauma". Analecta Husserliana 86: 209-221.

O'Connell, Mark. "The Empathic Paradox: Third-Person Narration in John Banville's FirstPerson Narratives". ORBIS Litterarum 66.6 (2011): 427-447.

—. John Banville's Narcissistic Fictions. Basingstoke and New York: Palgrave Macmillan, 2013.

Peeren, Esther. The Spectral Metaphor: Living Ghosts and the Agency of Invisibility. Basingstoke and New York: Palgrave Macmillan, 2014.

Powell, Kersti Tarien. "The Lighted Windows: Place in John Banville's Novels". Irish University Review 36.1 (Spring-Summer 2006): 39-51.

Rimmon-Kenan, Shlomith. Narrative Fiction Contemporary Poetics. New York: Methuen, 1973.

Schwall, Hedwig. "'Mirror on Mirror Mirrored Is all the Show': Aspects of the Uncanny in Banville's Work with a Focus on Eclipse". Irish University Review 36.1 (SpringSummer 2006): 116-133.

Smith, Eoghan. "It's That Man Again". Dublin Review of Books. 1 September 2015. 10 May 2017. www.drb.ie/essays/it-s-that-man-again

Wilkinson, Robin. "Echo and Coincidence in John Banville's Eclipse". Irish University Review 33.2 (Autumn-Winter 2003): 356-370.

Mar Asensio Aróstegui is Senior lecturer at the University of La Rioja, Spain. She graduated in English Studies at the University of Zaragoza, completed a Master of Arts in Studies in Fiction at the University of East Anglia (for which she received support from La Caixa and 
The British Council) and her doctorate at the University of Zaragoza. She works largely on twentieth- and twenty-first-century British and North-American literature and film, with particular interests in the theory of narratology, gender issues, identity, and trauma. She has presented her research at international conferences and published academic articles and book chapters on the works of Jeanette Winterson, Doris Lessing, Evelyn Waugh, Wyndham Lewis or Don DeLillo, and on films by Ridley Scott, Peter Weir or Woody Allen. She edited the Journal of English Studies from 2006 to 2009. She teaches English, Literary Theory, and Contemporary British and American Literature at the University of La Rioja.

mar.asensio@unirioja.es 